\title{
Genetikk ved kronisk obstruktiv lungesykdom
}

\begin{abstract}
Sammendrag
Bakgrunn. Kronisk obstruktiv lungesykdom (kols) forårsakes primært av miljøfaktorer som røyking og yrkeseksponering. Forskning tyder imidlertid på at sykdommen også har en betydelig genetisk komponent. Denne artikkelen gir en kort innføring i metoder for påvisning av genetisk disposisjon og en oversikt over nåværende kunnskap om sammenhengen mellom genetiske faktorer og kols.
\end{abstract}

Materiale og metode. Bakgrunn for artikkelen er egne vitenskapelige studier og en ikke-systematisk litteraturgjennomgang i PubMed.

Resultater. Den eneste kjente genetiske årsak til kols, alfa-1-antitrypsinmangel, forekommer hos svært få av pasientene, men mye tyder på at andre genetiske faktorer påvirker utvikling av sykdommen. Familiestudier har vist familiær opphopning av redusert lungefunksjon, og koblingsstudier har vist at sykdomsgener kan finnes på flere kromosomer. Et gen lokalisert på kromosom 2, SERPINE2, er blitt forbundet med kols i flere assosiasjonsstudier, også i den norske befolkningen. Andre kandidatgener har i liten grad latt seg reprodusere i befolkningsstudier. Nylig har man i en genomvid assosiasjonsstudie identifisert to gener som kan være involvert i kols - HHIP på kromosom 4 og CHRNA 3/5 på kromosom 15. Hvilken rolle disse genene spiller i sykdomsutviklingen, er foreløpig ukjent.

Fortolkning. Det er sannsynlig at mange ulike gener og miljøfaktorer påvirker utviklingen av en så kompleks og heterogen sykdom som kols.
Inga-Cecilie Sørheim

inga.cecilie.soerheim@helse-bergen.no

Lungeavdelingen

Haukeland universitetssykehus

5021 Bergen

Amund Gulsvik

Per Sigvald Bakke

Lungeavdelingen

Haukeland universitetssykehus

og

Institutt for indremedisin

Universitetet i Bergen

Jan Christian Brøgger

Institutt for klinisk medisin

Seksjon for nevrologi

Universitetet i Bergen

Thomas Blix Grydeland

Lungeavdelingen

Haukeland universitetssykehus

og

Institutt for indremedisin

Universitetet i Bergen

Edwin K. Silverman

Brigham and Women's Hospital

Harvard Medical School

Karakteristisk for kols er en luftveisobstruksjon som ikke er fullstendig reversibel. De siste 40 år er spirometri - med lungefunksjonsmålene forsert ekspiratorisk volum på ett sekund $\left(\mathrm{FEV}_{1}\right)$ og forsert vitalkapasitet (FVC) - blitt brukt til diagnostikk og klassifisering (1). Kols er en svært vanlig sykdom i Norge. Anslagsvis 200000 mennesker er rammet, og det er ca. 30000 nye tilfeller per år $(2-4)$.

Røyking og andre miljøfaktorer er de dominerende risikofaktorene for utvikling av kols, og det er holdepunkter for at det er et dose-respons-forhold mellom mengde tobakksrøyk og grad av lungesykdom. Samtidig er det mye som tyder på at også genetiske faktorer er av betydning. For det første er det vist at kun $15 \%$ av variabiliteten i FEV kan tilskrives røyking (5) og at det er et mindretall av røykerne som utvikler sykdommen. For det andre er det påvist familiær opphopning av redusert lungefunksjon.

Denne artikkelen gir en oversikt over metoder for påvisning av genetisk disposisjon og en sammenfatning av nåværende kunnskap innenfor feltet genetikk og kols.

\section{Materiale og metode}

Grunnlaget for artikkelen er et ikke-systematisk litteratursøk i PubMed med et skjønnsmessig utvalg av artikler basert på forfatternes kunnskaper innen feltet og i tillegg erfaringer fra egne studier.

\section{Genetiske begreper}

Genetiske studier gjøres på DNA-nivå, mens ekspresjonsstudier (som gir informasjon om geners aktivitet) gjøres på RNA-nivå. Proteomikk er studien av proteiners struktur og funksjon. Funksjonell genomforskning (genomikk) beskriver geners og proteiners funksjoner og interaksjoner (fig 1). Det er identifisert mange millioner steder i genomet der enkeltnukleotider i DNA-sekvensen kan variere mellom to mennesker. Disse variantene kalles polymorfismer. Som markører i genetiske studier benyttes ofte enkeltbasevarianter (single nucleotide polymorphisms). De fleste har ingen funksjonell effekt, men noen kan påvirke disposisjon for sykdom.

Med genotype menes et individs genetiske sammensetning, mens fenotype beskriver fysiske karakteristika eller egenskaper hos et individ. Ulike fenotyper ved kols kan bl.a. bygge på symptomer, klinisk diagnose, lungefunksjonsmålinger, funn ved bildediagnostikk eller inflammasjonsmarkører (6).

Sykdommer påvirket av gener kan være monogene (mutasjon i ett enkeltgen), polygene (flere gener) eller multifaktorielle/ komplekse (flere gener og miljøfaktorer). Kols er et typisk eksempel på en kompleks sykdom, med sannsynlig påvirkning fra en rekke gener og miljøfaktorer og interaksjoner mellom ulike gener og mellom gener og miljø (7).

\section{Påvisning av genetisk disposisjon.} Familiestudier av arvelighet

Opphopning av en kompleks sykdom i familier er ofte første holdepunkt for at en sykdom kan ha en genetisk komponent. I familiestudier sammenliknes risikoen for sykdom hos slektninger til den sykdomsaffiserte med risikoen i den generelle populasjonen. Påvisning av økt risiko for sykdom hos familie-

\section{Hovedbudskap}

- Kols forårsakes primært av miljøfaktorer, men har også en genetisk komponent

- Alfa-1-antitrypsinmangel er en kjent genetisk årsak til kols

- Nyere studier tyder på at mutasjoner i SERPINE2 og andre kandidatgener kan være av betydning

- Manglende reproduserbarhet av positive funn har vært et problem 


\section{Ramme 1}

\section{Kandidatgener som er blitt assosiert med kols, modifisert etter Silverman og medarbeidere (7)}

Proteaser

Alfa-1-antitrypsin (SERPINA 1) Alfa-1-antikymotrypsin (SERPINA 3)

Matriksmetalloprotease 1, 9, 12 (MMPx)

Serpinpeptidaseinhibitor, clade E, member 2 (SERPINE2)

Antioksidanter/oksidanter Superoksiddismutase 3 (SOD3) Hemoksygenase 1 (HMOX1)

Enzymer involvert i metabolisme/ detoksifisering

Mikrosomal epoksidhydrolase (EPHX1)

Glutation S-transferase P1 (GSTP1) Gluthation S-transferase M1 (GSTM1)

Inflammasjon

Tumornekrosefaktor alfa (TNF alfa)

Immunrespons

Surfaktantprotein B, D (SFTPB

SFTPD)

Vitamin D-bindende protein (GC)

Astmarelaterte gener

ADAM-metallopeptidase domene 33 (ADAM33)

Interleukin 10 (IL10)

Andre

Transformerende vekstfaktor beta-1

(TGFB1)

Alfanikotinreseptor (CHRNA3/5)

«Hedgehog»-interagerende protein (HHIP)

medlemmer kan skyldes at sykdommen er genetisk betinget, men det kan også skyldes opphopning av miljøfaktorer (f.eks. røyking) i familier. Ved tvillingstudier kan grad av arvelighet estimeres. Større overensstemmelse mellom eneggede tvillinger enn mellom toeggede tyder på arvelighet.

\section{Familiebaserte koblingsstudier}

Koblingsstudier benyttes for å finne regioner i genomet hvor genetiske determinanter for en sykdom er lokalisert. I disse studiene kan man anvende små familieenheter, f.eks. pasienter med foreldre, eller et større antall familiemedlemmer i familier der sykdommen opptrer (et slektstre). Dersom et gensegment opptrer hyppigere enn man skulle forvente hos de affiserte familiemedlemmene, tyder dette på at området kan være av betydning for sykdommen.

\section{Assosiasjonsstudier med kandidatgener}

Assosiasjonsstudier kan være både familieog populasjonsbaserte, men gjøres oftest $\mathrm{i}$ pasient-kontroll-studier. Ved denne metoden er målet å lokalisere mulige enkeltbasevarianter i kandidatgener som kan påvirke utviklingen av sykdom. Kandidatgener kan ha kjent eller ukjent funksjon og kan velges ut fra genekspresjonsstudier, ut fra hypoteser omkring sykdomsmekanisme eller fra områder påvist ved koblingsstudier. Enkeltbasevariantene har flere varianter (alleler), og man sammenlikner frekvensen av variantene i pasient- og kontrollgruppen. Signifikant forskjell i allelfrekvens mellom pasienter og kontrollpersoner kan ha flere årsaker (8): en enkeltbasevariant disponerer for sykdom, enkeltbasevarianten er lokalisert i nærheten av og arves sammen med sykdomsgenet (koblingsulikevekt) eller det kan være falskt positive assosiasjoner grunnet skjevhet (bias) (f.eks. etniske forskjeller), for lite utvalg eller statistisk tilfeldighet.

I tillegg til analyse av individuelle enkeltbasevarianter kan også koblede nærliggende enkeltbasevarianter på et kromosom (haplotyper) undersøkes med tanke på assosiasjon.

\section{Genomvide assosiasjonsstudier}

Nye teknologiske fremskritt har muliggjort genomvide assosiasjonsstudier (GWAS) (9), med bruk av mange hundre tusen enkeltbasevarianter spredt utover genomet. Bakgrunnen for utviklingen er bl.a. det internasjonale HapMap-prosjektet (10), en database over vanlige enkeltbasevarianter i genomet, samt tilgjengelig teknologi som har gjort genotyping av store antall enkeltbasevarianter billigere. Med denne metoden undersøkes store deler av genomet, med mulighet for å påvise hittil ukjente kandidatgener for en rekke sykdommer (11). Begrensningene ved genomvide studier er bl.a. at antall analyser øker risikoen for falskt positive assosiasjoner og at polymorfismer må være forholdsvis hyppig forekommende i befolkningen for å kunne oppdages. Metoden er velegnet til å lete etter nye kandidatgener og kan dermed virke hypotesegenererende.

\section{Genetisk disposisjon}

\section{Lungefunksjon}

Lungefunksjon målt ved spirometri er den mest brukte fenotypen i genetiske studier av kols. En rekke befolkningsstudier i Norge $(12,13)$ har vist at $30-70 \%$ av variasjonen i spirometriske variabler lar seg forklare ut fra kjønn, alder og kroppshøyde. Familiestudier fra Frankrike (14) og tvillingstudier fra Sverige (15) har vist at arv representerer nærmere $20-30 \%$ av variasjonen i lungefunksjon etter justering for alder, kjønn, høyde og røykevaner. Koblingsanalyser med lungefunksjonsmål er gjort i flere familiestudier i USA. Noen grad av kobling for $\mathrm{FEV}_{1}$ og $\mathrm{FEV}_{1} / \mathrm{FVC}$ er funnet til kromosom 6, mens FVC var koblet til kromosom 21 (16). I en annen studie fant man kobling mellom $\mathrm{FEV}_{1} / \mathrm{FVC}$ og kromosom 4, mens $\mathrm{FEV}_{1}$ og FVC var koblet til kromosom 18 (17). Så langt har det vært manglende reproduserbarhet av disse funnene.

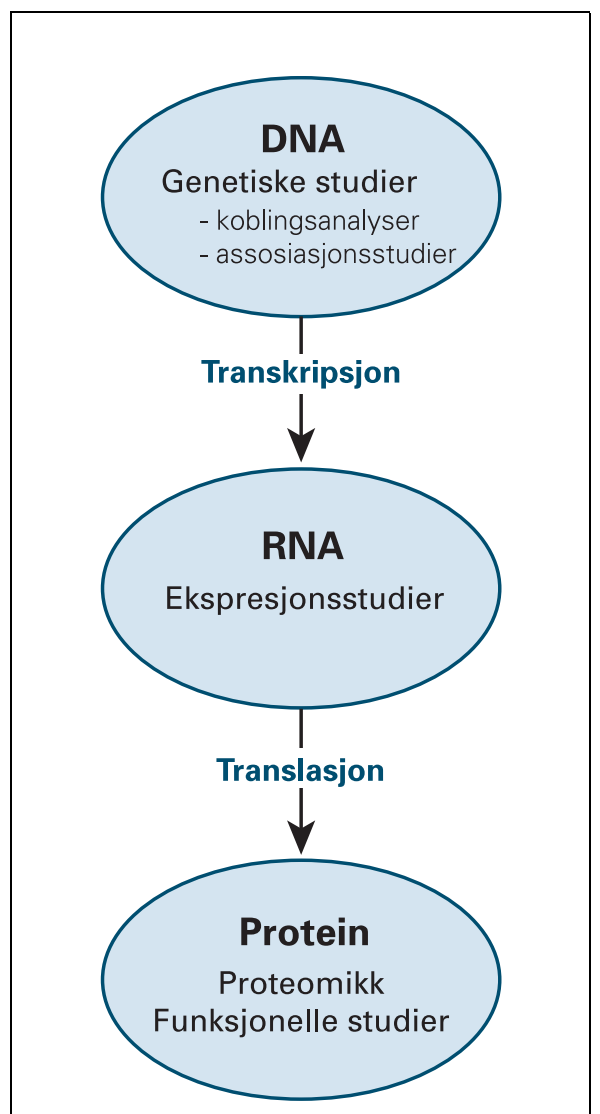

Figur 1 Genomforskning på ulike nivåer

\section{Alfa-1-antitrypsinmangel}

Alvorlig mangel på alfa-1-antitrypsin er en kjent genetisk risikofaktor for kols. Alfa-1antitrypsin er et protein som kodes fra SERPINA1-genet på kromosom 14. De opprinnelig påviste variantene (18) ble benevnt etter deres elektroforetiske migrasjon: $F$ (fast), $\mathrm{M}$ (medium), $\mathrm{S}$ (slow) og $\mathrm{Z}$ (very slow). Betydelig økt risiko for kols finnes hos røykere som er homozygote for proteaseinhibitorfenotype ZZ (forekomst 0,06\% i Norge). Samtidig er det noen ZZ-personer som ikke utvikler lungesykdom, noe som tyder på at andre gener og miljøfaktorer modifiserer effekten. Risiko ved fenotype MZ er grundig undersøkt. En befolkningsstudie fra Oslo viste at de som var heterozygote for $Z$ ikke hadde mer obstruktiv sykdom enn de med fenotype MM (19), men dette er fortsatt uavklart (20).

\section{Kols uten alfa-1-antitrypsinmangel}

Kun en liten del av kolstilfellene skyldes alfa-1-antitrypsinmangel (19). Flere andre gener er trolig av betydning. En eldre tvillingstudie har vist betydelig familiær opphopning av hoste i noen familier av røykere (21). En annen studie viste at en familieanamnese med kronisk bronkitt og emfysem ga en oddsratio på 5,2 for at vedkommende selv hadde de samme sykdommene (22). Hos pasienter i Boston, USA, med tidlig debut av alvorlig kols hadde nære slektninger betydelig økt risiko for kronisk bronkitt og lav $\mathrm{FEV}_{1}$-måling (23). 
Det er foreløpig bare publisert én koblingsstudie for kvalitative og kvantitative fenotyper ved kols $(24,25)$. Mulige koblinger ble funnet til kromosom 22 for kronisk bronkitt hos røykere og til kromosom 12 for lav $\mathrm{FEV}_{1}$-måling hos røykere. $\mathrm{FEV}_{1}$ viste kobling til flere områder, mest uttalt til kromosom 8 og kromosom 1 . $\mathrm{FEV}_{1} / \mathrm{FVC}$-ratio viste sterk grad av kobling til kromosom 2 og, i mindre grad, til kromosom 1. På den lange armen til kromosom 2 identifiserte man kandidatgenet SERPINE2 ved genekspresjonsstudier av lungevev.

Både familiebaserte studier og pasientkontroll-studier har vist assosiasjon mellom SERPINE2 og kols (26), men en annen forskningsgruppe var ikke i stand til å bekrefte dette (27). Assosiasjonen ble deretter bekreftet i ytterligere to populasjoner - en familiestudie fra Europa/USA og en pasientkontroll-studie fra Bergen (28). For fem av de 25 enkeltbasevariantene som ble testet var det en assosiasjon mellom SERPINE2genet og kols i begge studiene. At funnet ble reprodusert i to store, uavhengige populasjoner, gir sterke holdepunkter for at SERPINE2 kan være et sykdomsgen. Hvilken rolle det eventuelt har i sykdomsutviklingen, er ennå ukjent.

I Bergen har vi utført assosiasjonsstudier med andre kandidatgener i det samme pasient-kontroll-materialet. I disse studiene testet vi enkeltbasevarianter i kandidatgenene $A D A M 33$, LTA, ADRB2, EPHX1 og TNF. Ved analyse av en firedel av materialet fant vi en svak beskyttende effekt av en polymorfisme i $E P H X 1$-genet (29), men ved analyse av hele materialet fant vi ingen overbevisende assosiasjon til noen av enkeltbasevariantene (30). Ved å skille pasienter og kontrollpersoner i mer ekstreme lungefunksjongrupper fant vi imidlertid assosiasjon til en enkeltbasevariant i TNF-genet (31).

Nylig ble den første genomvide assosiasjonsstudien for kols publisert. En av de undersøkte populasjonene var den nevnte pasient-kontroll-studien fra Bergen (32). Det ble identifisert to nye områder i genomet med assosiasjon til kols. CHRNA 3/5-genet ligger på kromosom 15 og koder for en nikotinreseptor. Dette genet har også vært assosiert med lungekreft i flere studier (33-35). Det er imidlertid uklart om dette virkelig er et sykdomsgen eller om det kun er involvert i nikotinavhengighet. HHIP-genet koder for «hedgehog»-interagerende protein og er lokalisert på kromosom 4. Man tror at dette genet kan være involvert i lungeutvikling, men funksjonen i kolssammenheng er ukjent. En annen genomvid studie har vist at HHIP er assosiert med lungefunksjon (36).

\section{Manglende reproduserbarhet}

I de fleste assosiasjonsstudier har man satt søkelys på mutasjoner i gener som påvirker proteaser/antiproteaser, antioksidanter/oksidanter, betennelsesreaksjoner, immunrespons og astma (ramme 1). Gjennomgående har den

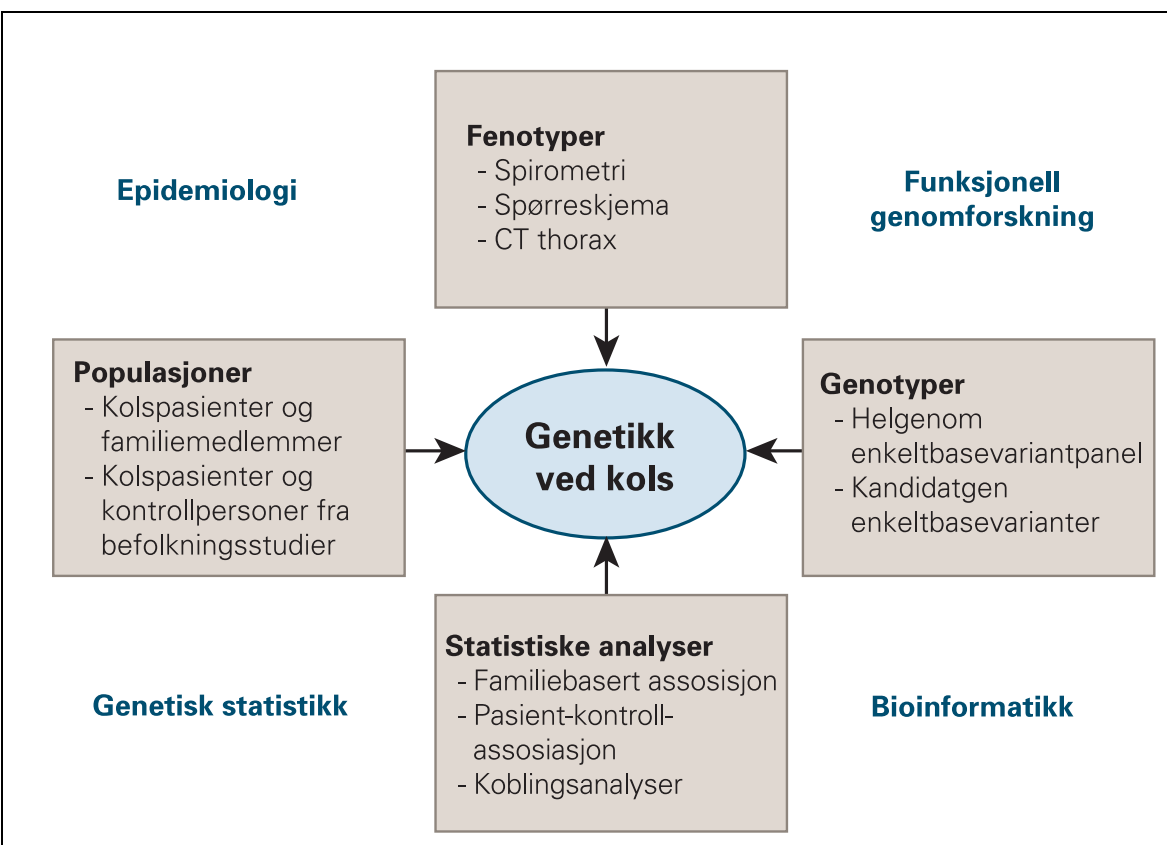

Figur 2 Tverrfaglig tilnærming til genetikk ved kols, modifisert etter Silverman og medarbeidere (7)

første publiserte studien vist en positiv assosiasjon, mens man i senere studier ikke har klart å reprodusere funnene (37). Det er flere årsaker til inkonsistente resultater og manglende reproduserbarhet (38). Et viktig problem har vært forskjellige pasientdefinisjoner (fenotypisk heterogenitet). I tillegg har definisjonen av kols variert over tid. Flere genetiske årsaker til samme sykdom (genetisk heterogenitet) er også en mulig forklaring. Dersom pasienter og kontrollpersoner kommer fra ulike populasjoner og har ulik genetisk bakgrunn, kan falskt positive sammenhenger oppstå - et fenomen kjent som populasjonsstratifisering. Lavt deltakerantall i studiene, statistiske utfordringer eller ufullstendig penetrans kan være andre årsaker.

\section{Fremtidige forskningsretninger}

Forskning på genetisk komplekse sykdommer er tverrfaglig og omfatter analyser av fenotyper og genotyper i aktuelle populasjoner med relevante statistiske metoder (fig 2). Denne forskningen kan bidra til oppdagelsen av nye markører for sykdommen, noe som kan være et verdifullt redskap både diagnostisk og prognostisk. Kunnskap om genetikk kan også gi innsikt i hittil ukjente sykdomsmekanismer og kan på sikt åpne for nye behandlingsmuligheter.

Teknologiske fremskritt gir stadig nye muligheter innenfor genetisk forskning. Fremover vil flere genomvide studier bli utført, og det å reprodusere positive funn i flere uavhengige befolkninger vil stå sentralt. Stor interesse knytter det seg også til fagfeltet proteomikk, der man håper å kunne måle proteiner i celler, vev og kroppsvæsker på samme måte som man måler RNA ved ekspresjonsstudier.
I klinisk forskning bør bedre standardisering av fenotypene og karakterisering av pasientene ha høy prioritet, slik at ulike studier blir sammenliknbare. Kols er en heterogen sykdom, og dersom et gen er viktig for en spesiell fenotype, f.eks. emfysem, finner man ikke nødvendigvis en assosiasjon dersom alle med en kolsdiagnose er blitt inkludert. Fremover bør man legge vekt på å sammenlikne genotyper med mer spesifikke fenotyper, f.eks. basert på CT-funn, andre lungefunksjonsmål, biomarkører eller fall i lungefunksjon over tid. Den genetiske bakgrunnen for nikotinavhengighet må undersøkes nærmere, det samme må interaksjoner mellom ulike gener og mellom gener og miljøfaktorer. Store internasjonale multisenterstudier med pasienter, familiemedlemmer og kontrollpersoner som følges over tid bør være idealet.

Genetiske studier av kols er i sin begynnelse, og mye er fortsatt ukjent. Forhåpentligvis vil videre forskning gi svar på hvilke gener som påvirker utviklingen av kols og identifisere de ulike genetiske varianter som er av betydning for sykdomsutviklingen.

Oppgitte interessekonflikter: Inga-Cecilie Sørheim har mottatt TravelAward fra GlaxoSmithKline og holdt foredrag for Astra-Zeneca. Edwin K. Silverman har mottatt honorar fra GlaxoSmithKline, Wyath, Bayer og Astra-Zeneca. Jan Christian Brøgger har mottatt honorar for deltakelse i oppstart av en genetisk assosiasjons-studie av kols fra Innovest AS, sponset av GlaxoSmithKline. Per Sigvald Bakke er hovedansvarlig for den norske delen av en internasjonal studie om kols hvor genetiske problemstillinger er inkludert. De andre forfatterne har ingen oppgitte interessekonflikter. 


\section{Litteratur}

1. Gulsvik A, Bakke PS. Lungesykdommer. En basal innføring. Bergen: Fagbokforlaget, 2004

2. Johannessen A, Omenaas ER, Bakke PS et al. Implication of reversibility testing on prevalence and risk factors for chronic obstructive pulmonary disease: a community study. Thorax 2005; 60: 842-7.

3. Johannessen A, Omenaas ER, Bakke P et al. Incidence of GOLD-defined chronic obstructive pulmonary disease in a general adult population. Int J Tuberc Lung Dis 2005; 9: 926-32.

4. Buist AS, McBurnie MA, Vollmer WM et al. International variation in the prevalence of COPD (The BOLD Study): a population-based prevalence study. Lancet 2007; 370: 741-50.

5. Burrows B, Knudson RJ, Cline MG et al. Quantitative relationships between cigarette smoking and ventilatory function. Am Rev Respir Dis 1977; 115: 195-205.

6. Celli BR. Chronic obstructive pulmonary disease phenotypes and their clinical relevance. Proc Am Thorac Soc 2006; 3: 461-5.

7. Silverman EK, Shapiro SD, Lomas DA et al. Respiratory genetics. London: Hodder Arnold, 2005.

8. Silverman EK, Palmer LJ. Case-control association studies for the genetics of complex respiratory diseases. Am J Respir Cell Mol Biol 2000; 22: 645-8.

9. Hirschhorn JN, Daly MJ. Genome-wide association studies for common diseases and complex traits. Nat Rev Genet 2005; 6: 95-108.

10. The International HapMap Consortium. A haplotype map of the human genome. Nature 2005; 437 : $1299-320$

11. The Wellcome Trust Case Control Consortium. Genome-wide association study of 14000 cases of seven common diseases and 3000 shared controls. Nature 2007; 447: 661-78.

12. Gulsvik A, Tosteson T, Bakke P et al. Expiratory and inspiratory forced vital capacity and onesecond forced volume in asymptomatic neversmokers in Norway. Clin Physiol 2001; 21: 648-60.

13. Johannessen A, Lehmann S, Omenaas ER et al. Post-bronchodilator spirometry reference values in adults and implications for disease management. Am J Respir Crit Care Med 2006: 173: $1316-25$.

14. Kauffmann F, Tager IB, Munoz A et al. Familial factors related to lung function in children aged 6-10 years. Results from the PAARC epidemiology study. Am J Epidemiol 1989; 129: 1289-99.
15. McClearn GE, Svartengren M, Pedersen NL et al. Genetic and environmental influences on pulmonary function in aging Swedish twins. J Gerontol 1994; 49: 264-8.

16. Joost O, Wilk JB, Cupples LA et al. Genetic loci influencing lung function: a genome-wide scan in the Framingham study. Am J Respir Crit Care Med 2002; 165: 795-9.

17. Wilk JB. DeStefano AL, Arnett DK et al. A genomewide scan of pulmonary function measures in the national Heart, Lung and Blood Institute Family Heart Study. Am J Respir Crit Care Med 2003; 167 1528-33.

18. Fagerhol MK, Laurell CB. The Pi system inherited variants of serum alfa 1-antitrypsin phenotypes. Prog Med Genet 1970; 7: 96-111.

19. Gulsvik A, Fagerhol MK. Alpha 1-antitrypsin phenotypes and obstructive lung disease in the city of Oslo. Scand J Resp Dis 1979; 60: 267-74.

20. Hersh CP, Dahl M, Ly MP et al. Chronic obstructive disease in alpha-1-antitrypsin PI MZ heterozygotes: a meta-analysis. Thorax 2004; 59: 843-9.

21. Cederlof R, Edfors ML, Friberg $L$ et al. Hereditary factors, «spontaneous cough» and «smokers cough». A study of 7800 twin pairs with the aid of marked questionnaires. Arch Environ Health 1967 14: 401-6.

22. Montnemery $\mathrm{P}$, Lanke J, Lindholm LH et al. Familial related risk-factors in the development of chronic bronchitis as compared to asthma assessed in a postal survey. Eur J Epidemiol 2000; 16: $1003-7$.

23. Silverman EK, Chapman HA, Drazen JM et al. Genetic epidemiology of severe, early onset chronic obstructive pulmonary disease. Risk to relatives for airflow obstruction and chronic bronchitis. Am J Respir Crit Care Med 1998; 157: 1770-8.

24. Silverman EK, Palmer LJ, Mosley JD et al. Genome-wide linkage analysis of severe, earlyonset chronic obstructive pulmonary disease: airflow obstruction and chronic bronchitis phenotypes. Hum Mol Genet 2002; 11: 623-32.

25. Palmer LJ, Celedón JC, Chapman HA et al. Genome-wide linkage analysis of bronchodilator responsiveness and postbronchodilator spirometric phenotypes in chronic obstructive pulmonary disease. Hum Mol Genet 2003: 12: 1199-210. Rettelse: Hum Mol Genet 2003; 12: 2085.

26. DeMeo DL, Mariani TJ, Lange $C$ et al. The SERPINE2 gene is associated with chronic obstructive pulmonary disease. Am J Hum Genet 2006; 78: 253-64
27. Chappel S, Daly L, Morgan Ket al. The SEREPINE2 gene and chronic obstructive pulmonary disease. Am J Hum Genet 2006; 79: 184-6.

28. Zhu G. Warren L, Aponte J et al. The SERPINE2 gene is associated with chronic obstructive pulmonary disease in two large populations. Am J Resp Dis Crit Care 2007; 176: 167-73.

29. Brøgger J, Steen VM, Eiken HG et al. Genetic association between COPD and polymorphisms in TNF. ADRB2 and EPHX1. Eur Respir J 2006: 27: 682-8.

30. Grydeland T, Silverman EK, Gulsvik A et al. Association analysis of ADAM 33, TNF, EPHX1, and ADRB2 polymorphisms (SNPs) with COPD in a large community sample. Abstrakt. Proc Am Thorac Soc 2006; 3: A503

31. Sørheim IC, Grydeland TB, Gulsvik A et al. Are ADAM33, TNF, LTA, EPHX1 and ADRB2 polymorphisms (SNPs) associated with COPD in a large case-control study when cases and controls are purified? Abstrakt. Eur Respir J 2007; 30 (suppl 51): P873.

32. Pillai SG, Ge D, Zhu G et al. A genome-wide association study in chronic obstructive pulmonary disease (COPD): identification of two major susceptibility loci. PLoS Genet 2009; 5: e1000421.

33. Amos Cl, Wu X, Broderick P et al. Genome-wide association scan of tag SNPs identifies a susceptibility locus for lung cancer at 15q25.1. Nat Genet 2008; 40: 616-22

34. Hung RJ, McKay JD, Gaborieau V et al. A suscetibility locus for lung cancer maps to nicotinic acetylcholine receptor subunit genes on 15q25. Nature 2008: 452: 633-37.

35. Thorgeirsson TE, Geller F, Sulem $P$ et al. A variant associated with nicotine dependence, lung cancer and peripheral arterial disease. Nature 2008; 452 638-42.

36. Wilk JB, Chen TH, Gottlieb DJ et al. A genomewide association study of pulmonary function measures in the Framingham Heart Study. PLoS Genet 2009; 5: e1000429.

37. Hersh CP. Demeo DL, Lange $C$ et al. Attempted replication of reported chronic obstructive pulmonary disease candidate gene associations. Am J Respir Cell Mol Biol 2005; 33: 71-8.

38. Silverman EK. Progress in chronic obstructive pulmonary disease genetics. Proc Am Thorac Soc 2006; 3: 405-8.

Manuskriptet ble mottatt 30.10. 2007 og godkjent 25.6. 2009. Medisinsk redaktør Erlend Hem. 